\title{
Optimizing the Technological Process of RO-LA TRANSPORT
}

\author{
MlinARIC, T.J.; Plesa, T. \& BARIC, D.
}

Abstract: The objective of the combined and intermodal transport is to connect by advanced technologies two or more traffic subsystems (road, rail, sea and river) into a continuous logistic transport chain that emphasises the systemic advantages and the power of single traffic branches, and enables their rational utilization. A component of intermodal transport is also Ro-La technology with specialized terminals that are studied in this paper regarding their technical and technological parameters. The integration of Croatia into the modern traffic flows of goods in Europe and the world is not possible unless advanced technologies of combined transport are implemented, i.e. unless adequate infrastructure and mobile means for combined transport are provided. Combined traffic enables integration into new requirements of international trade and world market, as well as integrity of production and transportation.

Key words: combined and intermodal transport, RO-LA technology, Case Study RoLa Spačva
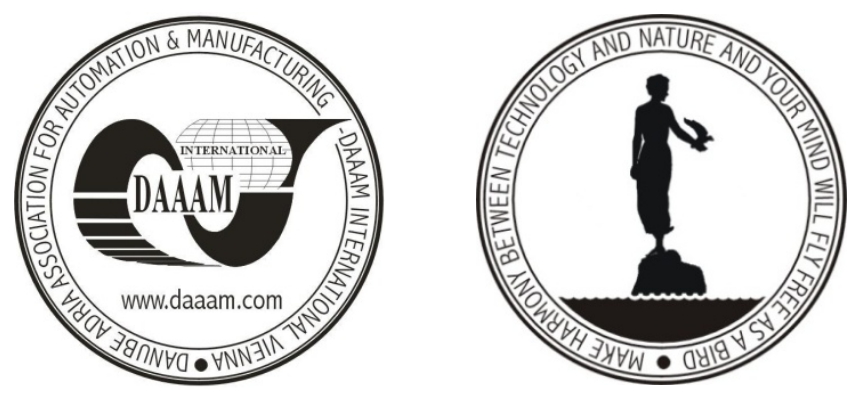

Authors' data: Dr. Mlinaric, T[omislav] J[osip]; Plesa, T[ihomir]; Baric, $\mathrm{D}$ [anijela], Faculty of transport and traffic sciences - University of Zagreb, Vukelićeva 4, 10000,Zagreb, mlinaric@fpz.hr, tihomir@fpz.hr, dbaric@fpz.hr

This Publication has to be referred as: Mlinaric, T[omislav] J[osip]; Plesa, T[ihomir] \& Baric, D[anijela] (2008). Optimizing the Technological Process of ROLA Transport, Chapter 43 in DAAAM International Scientific Book 2008, pp. 509524, B. Katalinic (Ed.), Published by DAAAM International, ISBN 978-3-90150966-7, ISSN 1726-9687, Vienna, Austria

DOI: $10.2507 /$ daaam.scibook.2008.43 